\title{
DINAMIKA STUDI ISLAM DI BARAT
}

\author{
M. Rusydi \\ Fakultas Ushuluddin dan Humaniora \\ IAIN Antasari Banjarmasin
}

Diterima tanggal 9 Januari 2016 / Disetujui tanggal 15 Maret 2016

\begin{abstract}
:
The following writing shows the historicity of Islamic studies in the West. It is important to reflect, at least as a comparison for our Islamic studies in Indonesia. Initially, Islamic studies in the West were looked unfairly. Islam was considered a fragment of Jews and Christian tradition. Thus, Islamic studies were positioned as a subunit of Christian studies. At this condition, Islamic studies tended to be colonized by West scholars' ideology. However, in 1980, Islamic studies began to be looked fairly in the West. Funded by National Endowment for the Humanities, University of Arizona for the first time held an international symposium on Islam and Religious Studies. In this symposium, Islam was considered equally with Christian. Therefore, the research on it was not only about Islam as religion but also as civilization. It was indicated by various approaches to Islam such as philology, social and humanities approaches. Today, Islamic studies develop intensively with the contemporary approaches called post-orientalism which is based on post-colonialism, post-structuralism, multiculturalism, and critical theory.
\end{abstract}

Kata kunci: Dinamika, Orientalisme, Post-Orientalisme, Studi Islam

\section{Pendahuluan}

Peristiwa 11 September yang menggoncangkan dunia, bisa saja menjadi salah satu sebab penting yang menjadikan perhatian dunia bertanya-tanya tentang Islam. Namun upaya pengkajian Islam yang intensif, terutama oleh para pemikir studi-studi agama dunia, di Barat-lah penyebab utama perkembangan kajian studi Islam di dunia. Mereka berupaya merumuskan, mencari problem dan solusi yang terbaik untuk seluruh problem-problem agama terutama Islam.

Dalam proses kajian akademis ini ditemukan bahwa Islam selama ini kurang mendapatkan perhatian dari para sarjana Barat bahkan cenderung diisolasikan dalam kesejarahan agama Kristen saja. Kajian tentang Islam pun masih cenderung pada ranah Islam sebagai agama saja, belum menyentuh ranah peradabannya, sehingga kajiannya lebih difokuskan pada kesejarahan dan teks-teks yang dimilikinya. Parahnya, kajian inipun masih cenderung terjebak pada kepentingan ideologis Barat saat itu.

Proses selanjutnya, ketika analisis sosial dan humaniora semakin tajam, kondisi-kondisi di atas mulai dikritik dan diperbaiki. Islam mulai dilihat sebagai agama dan peradaban. Islam tidak lagi hanya dilihat sebatas sejarah dan teks namun juga keseluruhan kompleksitas sosial dan budaya yang meliputi pengikutnya. Posisinya sebagai objek kajian pun menjadi setara dengan agama lain semacam agama Kristen. Kondisi ini ikut mengembangkan perangkat analisis dan pendekatan terhadap Islam terutama oleh ilmu-ilmu sosial dan humaniora sehingga Islam semakin aktual dan lebih diapresiasi. Demikianlah gambaran ringkas dinamika studi Islam di Barat yang akan diuraikan pada tulisan berikut ini. 
Abad pertengahan (medieval period) adalah masa kemunculan negara-negara Barat ke pentas dunia. Pada masa ini, negara Barat (Eropa) mulai melakukan interaksi dengan masyarakat Islam di negara-negara lain. Interaksi ini pada akhirnya berujung dengan penjajahan terhadap dunia Timur; India, Cina, Birma dan lain sebagainya. Tidak sedikit negara Timur yang dijajah oleh Barat tersebut berpenduduk muslim. Demi kepentingan penjajahan tersebut, negara Barat memerlukan berbagai pengetahuan tentang masyarakatnya bahkan agamanya sehingga mereka mengirimkan para sarjana untuk mengkajinya. Dari sinilah muncul istilah ahli ketimuran, atau lazimnya disebut dengan orientalisme. ${ }^{1}$

Orientalis adalah kata serapan dari bahasa Perancis yang asal katanya adalah orient yang berarti "Timur". Secara geografis, kata ini dapat diartikan "dunia Timur" dan secara etnologis berarti bangsa-bangsa di timur. Kata orient itu telah memasuki berbagai bahasa di Eropa, termasuk bahasa Inggris. Oriental adalah sebuah kata sifat yang bermakna; hal-hal yang bersifat timur, yang teramat luas ruang lingkupnya. ${ }^{2}$

Orientalis adalah kata nama pelaku yang menunjukkan seorang ahli tentang hal-hal yang berkaitan dengan "timur". Sedangkan kata orientalisme (Belanda) ataupun orientalism (Inggris) menunjukkan pengertian tentang suatu paham. Jadi orientalisme berarti sesuatu paham, atau aliran, yang berkeinginan menyelidiki halhal berkaitan dengan bangsa-bangsa di Timur beserta lingkungannya. ${ }^{3}$ Selain itu, Edward W. Said memahami orientalis sebagai suatu cara untuk memahami dunia Timur, berdasarkan tempatnya yang khusus menurut pengalaman orang Barat Eropa. ${ }^{4}$ Dengan kata lain, orientalisme adalah gaya berpikir yang berdasarkan pada pembedaan ontologis dan epistemologis yang dibuat antara "Timur" (the Orient) dan Barat (the Occident). Dan ini memiliki dampak politis yang kuat bagi kepentingan Barat. ${ }^{5}$

Oleh karena itu, meskipun orientalis memiliki makna yang luas, yaitu segala sesuatu yang berkaitan langsung dengan bangsa-bangsa Timur beserta lingkungannya sehingga meliputi seluruh bidang kehidupan, namun secara sempit, orientalis dapat diartikan sebagai kegiatan ahli ketimuran Barat tentang agama-agama di Timur, khususnya agama Islam demi kepentingan mereka.

1. Konstruk Pikir

Oleh karena diliputi oleh kepentingan tertentu maka orientalisme dalam mengkaji ketimuran memunculkan beberapa pandangan yakni; 1) ada perbedaan mutlak dan perbedaan sistematik antara Barat yang rasional, maju, manusiawi dan superior, dengan Timur yang irrasional, terbelakang dan inferior. Menurut mereka, hanya orang Eropa dan Amerika yang merupakan manusia sesungguhnya, sedangkan orang AsiaAfrika hanya bertaraf setengah-manusia. ${ }^{6}$ 2) Orientalisme memandang bahwa Barat adalah pelaku (actor),

\footnotetext{
${ }^{1}$ A. Qodri Azizy, Pengembangan Ilmu-Imu Keislaman (Jakarta : Departemen Agama, 2003), 90.

${ }^{2}$ Harun Nasution, Islam Rasional: Gagasan dan Pemikiran (Bandung: Mizan, 1995), 39-40.

${ }^{3}$ Harun Nasution, Islam Rasional: Gagasan dan Pemikiran, 39-40.

${ }^{4}$ Edward W Said, Orientalisme, terj. Asep Hikmah (Bandung : Pustaka, 1996), 3.

${ }^{5}$ Azizy, Pengembangan Ilmu-Ilmu Keislaman, 91. Bahkan jika ditelaah tentang istilah Middle East (Timur Tengah) sebenarnya tidak hanya berfungsi sebagai istilah geografis namun lebih dari itu. Istilah ini dimunculkan oleh Alfred T. Mahan, ahli sejarah kelautan Amerika, pada tahun 1902. Istilah ini digunakan untuk menjelaskan jalur laut dari Suez hingga Singapura yang merupakan jalur penghubung yang sangat penting antara Timur Dekat dan Timur Jauh dan hubungannya dengan kerajaan Inggris. Istilah ini kemudian diadopsi oleh CIA pada perang dunia kedua dan sangat berguna selama perang dingin (cold war). Lihat Carl W. Ernst dan Richard C. Martin, "Introduction : Toward a Post-Orientalist Approach to Islamic Religious Studies", dalam Rethinking Islamic Studies, ed. Carl W. Ernst dan Richard C. Martin (Columbia : University of South Carolina Press, 2010), 4.
}

${ }^{6} \mathrm{M}$. Amien Rais, Cakrawala Islam (Bandung: Mizan, 1986), 243. 
sedangkan Timur hanyalah penanggap yang fasif. ${ }^{7}$ 3) Timur adalah wilayah yang tidak berkembang karena sering terjebak pada wacana-wacana zaman dulu. ${ }^{8}$ 4) Islam tidak lain adalah agama sempalan yang menyimpang dari tradisi Judaeo-Hellenic-Roman-Christian. ${ }^{9}$ Kondisi ini bisa dibandingkan, misalnya, pada awalawal pertengahan abad kedua puluh ketika terjadi pertemuan tahunan American Academy of Religion (AAR), saat itu Islam diposisikan sebagai sub unit dari kajian sejarah agama Kristen. ${ }^{10}$

Konstruk pikir seperti ini menjadikan kajian-kajian ketimuran, khususnya Islam, diperlakukan dengan kacamata subjek versus objek, ideologis, monolog dan dominan, serta dengan one-way interpretation sesuai kepentingan Barat saat itu.

\section{Pendekatan dan Metode}

Pada era ini, kajian-kajian keislaman dilihat dengan pendekatan orientalisme di atas dan diorientasikan pada filologi dan tekstual, dimana pengetahuan tentang bahasa dan sejarahnya merupakan dasar utama untuk penjelasan terhadap teks tersebut. Oleh karena itu, metode-metode yang dikembangkan saat itu adalah metode-metode filologis dan tekstual. Dengan pendekatan ini para pengkaji Islam ini berupaya memahami gagasan-gagasan dan konsep-konsep utama yang membentuk dunia muslim lewat teks (bahasa). Akibatnya memunculkan beberapa distorsi, diantaranya adalah; 1) kecenderungan memahami masyarakat Islam lewat teks berarti memahami masyarakatnya secara tidak langsung, sementara teks-teks yang dikaji kebanyakan berasal dari tradisi intelektual Islam klasik. ${ }^{11}$ 2) pendekatan tekstual ini juga mengakibatkan mereka menekankan kajian bahasa dengan pendekatan gramatikal dan etimologi yang sempit. Akibatnya, masyarakat Islam yang dipahami adalah masyarakat Islam non-kontekstual dan tidak unik. ${ }^{12}$

\section{Contoh Penelitian}

Ada banyak contoh penelitian yang bernuansa colonial interest, di sini dicontohkan dua saja; 1) H.A.R Gibb; meskipun Gibb simpati terhadap Islam sebagaimana ungkapannya bahwa "Islam is indeed much more than a system of theology, it is complete civilization", 13 namun menurut Amien Rais, jika diteliti dalam salah satu bukunya ia mengarahkan pembacanya supaya yakin bahwa pada zaman modern peranan Islam dalam kehidupan sosial pasti akan sirna. Berikut gambaran uraiannya;

sebagai agama dalam arti sempit, Islam hanya kehilangan sedikit kekuatannya. Namun sebagai penentu dalam kehidupan sosial di zaman modern, Islam sedang dicopot dari singgasananya. Dalam kehidupan modern terlalu banyak masalah yang tidak ada sangkut pautnya dengan Islam. Dalam hal ini, Islam tidak bisa berbuat apa-apa, kecuali menyerah pada keadaan, dan Islam akan ditelan oleh perkembangan zaman. ${ }^{14}$

${ }^{7}$ M. Amien Rais, Cakrawala Islam, 243.

${ }^{8}$ Bandingkan dengan A. Kevin Reinhart yang menyatakan "everywhere in Islamdom Arabic books are for sale, and these books are overwhelmingly medieval works". A. Kevin Reinhart, "Fundamentalism And The Transparency of The Arabic Qur'an", dalam Rethinking Islamic Studies, ed. Carl W. Ernst dan Richard C. Martin (Columbia : University of South Carolina Press, 2010$), 97$.

${ }^{9}$ Azizy, Pengembangan Ilmu-Imu Keislaman, 40

${ }^{10}$ Carl W. Ernst dan Richard C. Martin, "Introduction : Toward a Post-Orientalist Approach", 1.

${ }^{11}$ Bandingkan dengan footnote no. 8.

${ }^{12}$ Zakiyuddin Baidhawy, "Perkembangan Kajian Islam Dalam Studi Agama : Sebuah Pengantar", dalam Pendekatan Kajian Islam Dalam Studi Agama, ed. Richard C. Martin (Surakarta : Muhammadiyah University Press, 2001), xii-xiii.

${ }^{13}$ Amien Rais, Cakrawala Islam, 240.

${ }^{14}$ Amien Rais, Cakrawala Islam, 240. 
2) Philip K. Hitti dengan karyanya Islam and The West. Menurut Maryam Jamilah, Hitti beranggapan bahwa Islam tidak lain adalah warisan Yahudi-Kristen yang diarabisasikan. Di dalam bukunya tersebut diuraikan misalnya; ungkapan bahwa "sumber-sumber alquran itu jelas - orang-orang kafir Kristen, Yahudi dan Arab....Nabi Muhammad memiliki dua orang budak dari Habsyi (Ethiopia sekarang) yaitu muazzin beliau, Bilal, dan anak angkat beliau di belakang hari, Zaid...". ${ }^{15}$ Jadi seakan-akan ada anggapan bahwa Bilal dan Zaid yang berasal dari Habsyi yang memiliki tradisi Kristen bisa saja memberikan informasi tentang tradisi tersebut kepada Nabi Muhammad sehingga menjadi sebagian ayat-ayat yang ada di dalam alquran, terutama yang berkaitan dengan tradisi Kristen.

Demikianlah gambaran studi Islam di masa perkembangan orientalisme di Barat namun studi ini terus berlanjut hingga sekarang dengan nuansa yang lebih baik yakni bernuansa ilmiah-akademis.

\section{Studi Islam Sebagai Academic Purpose}

Maryam Jamilah menyatakan bahwa orientalisme tidak selalu buruk. Sejumlah pemikir besar di Barat, menurutnya, telah menghabiskan umurnya untuk mengkaji Islam lantaran mereka secara jujur tertarik terhadap kajian-kajian itu. Tanpa usaha mereka, banyak diantara pengetahuan berharga dalam buku-buku Islam kuno akan hilang atau tidak terjamah orang. ${ }^{16}$ Apalagi ketika Edward Said, yang dianggap sebagai penggagas post-kolonialisme, dengan memakai analisa pemikir Barat seperti Michel Foucault, mengkritik cara berpikir orientalisme di atas dan menyatakan bahwa ada relasi kuasa dan pengetahuan di dalam studi-studi orientalisme, terutama kajian tentang Islam berkaitan dengan kepentingan dalam upaya kolonialisme Barat terhadap dunia Timur, $^{17}$ sehingga muncullah upaya untuk membenahi citra ini. Albert Hourani misalnya mengajak para pemikir yang dicap sebagai orientalisme tersebut untuk menelaah ulang studi-studi Islam secara obyektif-ilmiah tanpa meributkan kecenderungan orientalisme di atas. ${ }^{18}$ Demikian juga Talal Asad mengkritik keras agar umat Islam dipahami sebagaimana adanya bukan dengan cara pandang bentukan Barat. ${ }^{19}$ Hasilnya Islam lebih diapresiasi sebagai agama dan peradaban bahkan telah menjadi salah satu program utama di American Academy of Religion (AAR) dan tidak lagi menjadi sub unit dari kesejarahan agama Kristen. ${ }^{20}$

1. Konstruk Pikir

Apresiasi terhadap kajian-kajian Timur, terutama Islam mulai berkembang bahkan Islam dipahami tidak lagi hanya sebagai agama tetapi juga sebagai peradaban. Islam sebagai peradaban berarti Islam dilihat tidak hanya lewat teks tetapi juga dari sosial budaya yang ada pada pengikutnya. Inilah yang disebut oleh Hodgson dengan istilah Islamicate. Islamicate adalah "something that "would refer not directly to the religion, Islam, itself,

${ }^{15}$ Maryam Jamilah, Islam dan Orientalisme, terj. Machnum Husein (Jakarta: Rajawali Press, 1994), 15.

${ }^{16}$ Maryam Jamilah, Islam dan Orientalisme, 11.

3.

${ }^{17}$ Carl W. Ernst dan Richard C. Martin, "Introduction: Toward a Post-Orientalist Approach to Islamic Religious Studies",

${ }^{18}$ Carl W. Ernst dan Richard C. Martin, "Introduction: Toward a Post-Orientalist Approach to Islamic Religious Studies",

3.

${ }^{19}$ Carl W. Ernst dan Richard C. Martin, "Introduction : Toward a Post-Orientalist Approach”, 9.

${ }^{20}$ Carl W. Ernst dan Richard C. Martin, "Introduction : Toward a Post-Orientalist Approach”, 1. 
but to the social and cultural complex historically associated with Islam and the Muslims, both among Muslims themselves and even when found among non-Muslims"."

Ketika para sarjana Barat ini mengkaji Islam mereka memperlakukannya sebagai objek studi yang sama dengan objek studi yang lain. Jadi tidak ada lagi perbedaan, misalnya, ketika mereka mengkaji Kristen atau objek studi yang lain. ${ }^{22}$ Di sinilah kajian-kajian Islam mulai dilihat secara akademis.

Dengan kajian-kajian seperti ini maka konstruk pikir yang membentuknya adalah cara pandang yang lebih humanistik, menafikan subjek versus objek, lebih bersifat komunikatif-emansipatoris, melihat Islam secara dialogis dan setara, serta memungkinkan terjadinya multi-interpretation dengan berbagai disiplin ilmu yang saling terkait. ${ }^{23}$

\section{Pendekatan, Metode, dan Contoh Penelitian}

Ketika kecenderungan akademis ini semakin menguat maka studi-studi keislaman mulai dikaji dengan beberapa pendekatan dan metode yang lebih variatif dari sebelumnya, sebagaimana berikut ini; 1) metode ilmu-ilmu yang masuk di dalam kelompok humaniora, seperti filsafat, filologi, ilmu bahasa, dan sejarah. Jadi Islam, terutama sekali ajaran-ajaran Islam, lewat karya para pemikirnya, yang sudah termuat di dalam teks-teks (buku-buku) dijadikan sasaran penelitian atau kajian melalui pendekatan atau metodologi penelitian yang biasa dilakukan sesuai dengan disiplin-disiplin yang masuk dalam kelompok humaniora tersebut. ${ }^{24}$ Diantara penulis yang pernah melakukan pendekatan ini misalnya adalah Azyumardi Azra dengan karyanya "Jaringan Ulama Timur Tengah dan Kepulauan Nusantara". ${ }^{25}$ 2) Bisa juga dengan menggunakan pendekatan yang biasa dipakai dalam disiplin atau kajian teologi agama. ${ }^{26}$ 3) Menggunakan metode ilmu-ilmu sosial, seperti sosiologi, antropologi, ilmu politik, dan psikologi (kadang-kadang psikologi dimasukkan ke dalam humaniora). Metodologi penelitiannya, tentu menggunakan metodologi yang biasa dipergunakan di dalam disiplin ilmuilmu sosial. Sebagai Contoh, Clifford Geertz dengan karyanya Religion of Java dengan pendekatan antropologi, kemudian Deliar Noer dengan karya The Modernist Muslim Movement in Indonesia dengan pendekatan ilmu politik. ${ }^{27}$ 4) Pendekatan studi wilayah (area studies), seperti studi wilayah Timur Tengah, studi Asia Tenggara atau studi bahasa dan peradaban Timur Dekat, dan lain sebagainya. Tokoh-tokoh yang lahir dengan pendekatan ini misalnya adalah Nurcholish Madjid dan Ahmad Syafi’i Ma’arif. Pendekatan yang digunakan di

${ }^{21}$ Carl W. Ernst dan Richard C. Martin, "Introduction : Toward a Post-Orientalist Approach", 8. (sesuatu yang merujuk secara tidak langsung kepada agama, Islam itu sendiri, namun merujuk kepada kompleksitas kesejarahan sosial budaya Islam dan Muslim, baik yang ada pada muslim itu sendiri atau yang ditemukan pada non-Muslim)

${ }^{22}$ Azizy, Pengembangan Ilmu-Ilmu Keislaman, 43.

${ }^{23}$ Bandingkan tulisan Ernst yang mengungkapkan "The essays in this volume, in contrast, are offered to exemplify and encourage the wider approach of the new, post-Orientalist Islamic studies. The authors of these articles are scholars at different stages of their careers; they focus on different texts, methodologies, and regions. However, they share the commitment to engage knowledge of the larger Islamic tradition with the tools of modern academic discourse in order to bring Islamic studies out of the ghetto of academic isolation,..." Lihat Carl W. Ernst dan Richard C. Martin, "Introduction : Toward a Post-Orientalist Approach", 14.

${ }^{24}$ Azizy, Pengembangan Ilmu-Ilmu Keislaman, 92. Mizan, 2004

${ }^{25}$ Lihat karya beliau, Azyumardi Azra, Jaringan Ulama Timur Tengah dan Kepulauan Nusantara Abad XVII \& XVIII (Bandung:

${ }^{26}$ Azizy, Pengembangan Ilmu-Ilmu Keislaman, 93.

${ }^{27}$ Azizy, Pengembangan Ilmu-Ilmu Keislaman, 93-94. 
sini pada umumnya bersifat interdisipliner atau disesuaikan dengan fokus kajian penelitian. ${ }^{28}$ Meskipun demikian, pendekatan studi wilayah ini masih meniscayakan penguasaan ilmu-ilmu sosial dan humaniora. ${ }^{29}$ Jadi sebenarnya bisa disimpulkan bahwa perangkat ilmu yang sangat penting untuk mendukung kajian-kajian Islam ini adalah ilmu-ilmu sosial dan humaniora, oleh karena itulah perkembangan teori-teori ilmu ini harus diikuti, seperti teori post-strukturalisme, gender dan feminisme, dekonstruksi, sastra kritis, post-kolonialisme, teori kritis, dan lain sebagainya. ${ }^{30}$

\section{Proses Historis Kajian Studi Islam: Dari Colonial Interest ke Academic Purpose}

Pada uraian sebelumnya telah diuraikan tentang karakteristik studi-studi keislaman yang mengalami perkembangan dari studi yang cenderung kolonial kepada studi yang ilmiah objektif. Pada bagian ini akan difokuskan bagaimana proses historis perkembangan tersebut terjadi.

Menurut Carl Ernst dan Richard Martins, ada tiga alasan utama mengapa kajian keislaman di Barat mulai diperhatikan secara intensif; 1) Sensitivitas ketidakpuasan masyarakat Muslim dan Islamisis terhadap kajian Islam di Barat yang cenderung menafikan Islam. ${ }^{31}$ 2) Munculnya para pemikir sejarah keislaman seperti Charles J. Adam, Montgomery Watt, Wilfred Cantwell Smith, dan lain sebagainya. ${ }^{32}$ 3) Adanya usaha untuk menuju kajian Islam yang "lebih adil". ${ }^{33}$

Adanya sensitivitas ketidakpuasan kaum muslim dan para Islamisis terhadap kajian keislaman ini muncul diantaranya dikarenakan adanya kecenderungan Islam diajarkan oleh para ahli dari jurusan Studi Wilayah dan Kajian Ketimuran (Orientalisme), ${ }^{34}$ sementara para ahli ini, sebagaimana diuraikan sebelumnya, cenderung mengajarkan Islam dalam kepentingan-kepentingan dominatif terhadap Islam. Di sisi lain, jurusan yang seharusnya bergelut dan sepertinya lebih berhak mengajarkan Islam sebagai sebuah agama yakni jurusan Sejarah Agama-Agama atau Studi-Studi Keagamaan menjadi tersisihkan oleh jurusan Studi Wilayah dan Kajian Ketimuran (Orientalisme). Hal ini tentu saja memicu "kecemburuan" yang berdampak pada ketegangan antara dua jurusan tersebut. ${ }^{35}$

Munculnya para pemikir sejarah keislaman seperti Charles J. Adam, Montgomery Watt, Wilfred Cantwell Smith, dan lain sebagainya, memiliki peranan yang sangat penting demi “menjembatani” ketegangan antara dua jurusan tersebut. Berawal dari kritik Edward Said pada tahun 1978, yang menyatakan bahwa Studi Wilayah dan Kajian Ketimuran (Orientalisme) cenderung melakukan kolonialisasi terhadap keilmuan-

${ }^{28}$ Azizy, Pengembangan Ilmu-Ilmu Keislaman, 95. Untuk seluruh metode dan pendekatan di atas bisa dibandingkan dengan tulisan Richard C. Martin, "Islam And Religious Studies : An Introductory Essay", dalam Approaches to Islam In Religious Studies, ed. Richard C. Martin (Tucson : The University of Arizona Press, 1985), 2.

${ }^{29}$ Azizy, Pengembangan Ilmu-Ilmu Keislaman, 95.

${ }^{30}$ Bandingkan ungkapan Ernst berikut "and of course the more recent phenomena of post-structuralism, deconstructive literary criticism, feminist and gender studies, post-colonial discourse, and the critique of Orientalism itself were all to influence scholarship over the decades after Adam's original essays. These more recent concern of Islamic and religious studies vibrate throughout the present work." Lihat Carl W. Ernst dan Richard C. Martin, "Introduction : Toward a Post-Orientalist Approach", 6.

${ }^{31}$ Lihat Carl W. Ernst dan Richard C. Martin, "Introduction : Toward a Post-Orientalist Approach", 7.

${ }^{32}$ Lihat Carl W. Ernst dan Richard C. Martin, "Introduction : Toward a Post-Orientalist Approach", 6.

${ }^{33}$ Lihat Carl W. Ernst dan Richard C. Martin, "Introduction : Toward a Post-Orientalist Approach", 6.

${ }^{34}$ Lihat Carl W. Ernst dan Richard C. Martin, "Introduction : Toward a Post-Orientalist Approach", 2.

${ }^{35}$ Lihat Carl W. Ernst dan Richard C. Martin, "Introduction : Toward a Post-Orientalist Approach", 2. 
keilmuan Timur sehingga kepentingan intelektual dan sosial ternafikan. ${ }^{36}$ Kemudian dilanjutkan oleh Albert Hourani tahun 1991 yang mengungkapkan bahwa Kajian-Kajian Ketimuran (Orientalisme) dalam pembacaan Barat terhadap studi-studi keislaman masih ideologis yakni europecentric. ${ }^{37}$ Pada sisi lain, yakni pada jurusan Sejarah Agama (Studi-Studi Agama), menurut Charles J. Adams, kajian-kajian ketimuran termasuk Islam cenderung diisolasikan, bahkan dianggap tidak penting di Barat. Hal ini dibuktikan oleh Adams dengan memperhatikan bahwa pada tahun 1967 di Universitas Chicago pada jurusan Perbandingan Agama sebagai bagian dari Kajian Sejarah Agama-Agama ditemukan bahwa kajian keislaman cenderung "mati suri” bahkan, menurutnya, sangat sulit sekali menemukan hubungan langsung antara aktivitas para ahli sejarah agama-agama tersebut dengan para ahli keislaman (islamisis). ${ }^{38}$ Selanjutnya, Adams juga berargumen bahwa pada tahun 1974 ketika ia menghadiri pertemuan tahunan AAR (American Academy of Religion), ternyata satu-satunya peserta yang berbicara tentang keislaman hanyalah dia sendiri, dan ini tentu saja, menurutnya, menunjukkan minimnya perhatian terhadap kajian keislaman. ${ }^{39}$

Dengan berbagai kritik yang muncul bagi dua jurusan tersebut, maka muncullah upaya untuk meletakkan Islam sebagai kajian yang "lebih adil" dan ilmiah. Untuk mencapai tujuan tersebut maka diadakanlah simposium internasional tentang Islam dan Sejarah Agama-Agama di Universitas Arizona pada tahun 1980. Kegiatan ini didanai oleh National Endowment for the Humanities. Pada simposium ini, ada lima belas pembicara yang diundang dari berbagai keahlian, seperti para ahli masalah haji, biografi Nabi Muhammad, konversi agama dalam Islam, ahli alquran dan hadis; selain itu juga para ahli agama Asia, Afrika, Eropa, Amerika dan lain sebagaimana; disertai pula para ahli ilmu-ilmu sosial dan humaniora seperti para ahli hermeneutika, studi ritual, gender, konversi agama, agama dan konflik dan lain sebagainya. Para ahli ini diundang dan diminta untuk mempresentasikan hasil "pembacaan" mereka terhadap Islam dengan perangkat penelitian dan metodologi ilmu-ilmu sosial dan humaniora. Akhirnya, tahun 1985, hasil dari simposium ini dibukukan dan diterbitkan dengan diedit oleh Richard C. Martins dengan judul Approaches to Islam in Religious Studies. Inilah upaya rintisan pertama untuk melihat data-data keislaman secara lebih jujur dan ilmiah. ${ }^{40}$

Kemudian, lanjutan dari simposium di atas, untuk melihat perkembangan dan perubahan yang terjadi pada studi-studi keislaman di era kontemporer ini, Carl Ernst dan Richard C. Martins, mengundang para pengkaji keislaman untuk menulis problematika keislaman dengan titik tekan pertanyaan; "bagaimana membaca teks-teks dan data-data Islam serta metodologi penelitiannya di abad dua puluh satu?” Hasilnya, para penulis tersebut menunjukkan bahwa kajian-kajian keislaman kontemporer telah mengalami kemajuan yang cukup signifikan yakni munculnya pendekatan-pendekatan baru yang disebut oleh Ernst dan Martins dengan pendekatan post-orientalisme yakni pendekatan yang berupaya membaca teks-teks dasar keislaman dengan analisis-analisis pemikiran kontemporer yang cenderung melampaui batas-batas disiplin dan wilayah 
(region) tertentu. ${ }^{41}$ Jika dibandingkan dengan simposium 1980 di atas, pada saat itu pemikiran yang cenderung dirujuk adalah tokoh-tokoh seperti Max Weber, Jack Goody, Victor Turner dan Clifford Geertz, maka pada perkembangan kontemporer ini tokoh yang sering dirujuk adalah tokoh-tokoh seperti Marshal Hodgson, Peter Brown, Talal Asad, Pierre Bourdie, Bryan Turner, Michel Foucault, Charles Taylor, Alaisdair MacIntyre, dan Kwame Anthony Appiah. ${ }^{42}$ Dalam tulisan-tulisan kajian Islam kontemporer ini lebih banyak ditemukan penggunaan teori-teori baru seperti teori kritis, teori post-strukturalisme, teori sastra kritis, gender dan feminism, post-kolonialisme, multikulturalisme serta teori-teori kosmopolit lainnya. ${ }^{43}$ Akhirnya pada tahun 2010, kumpulan tulisan tentang kajian keislaman kontemporer tersebut, yang merupakan lanjutan dari simposium 1980 ini diterbitkan oleh The University of South Carolina Press dengan judul Rethinking Islamic Studies : From Orientalism to Cosmopolitanism dan diedit oleh Carl W. Ernst dan Richard C. Martins.

\section{Kontribusi}

Meskipun orientalisme sering dilabeli dengan anggapan negatif, namun harus tetap dilihat secara objektif sebab dari orientalisme inilah lahirnya studi-studi keislaman terutama di Barat. ${ }^{44}$ Dengan perkembangan studi-studi keislaman di Barat itulah pada akhirnya kita dikenalkan dengan berbagai variasi pendekatan terutama yang berkembang dalam ilmu-ilmu sosial dan humaniora.

Dengan perkembangan tersebut, Islam sebagai objek kajian menjadi semakin menarik, "kaya", "membumi" dan layak untuk terus diteliti. Penelitian tersebut tentunya diharapkan bisa menjadikan Islam aktual sesuai dengan slogannya "selalu sesuai dengan perkembangan ruang dan waktu”" (rạmatan li al-âlamîn) dan diharapkan para pengikutnya semakin "dewasa" dalam mengembangkan dirinya, sebab berbagai kritik tentu saja akan ditemukan dengan cara pendekatan kontemporer ini. Kritik-kritik tersebut misalnya dapat ditemukan ketika membaca dua artikel yang terdapat dalam buku "Rethinking Islamic Studies" yang diedit oleh Carl W. Ernst dan Richard C. Martin, yakni, pertama, tulisan Vincent J. Cornell dengan judul "Reason Public and Divine : Liberal Democracy, Shari'a Fundamentalism, and the Epistemological Crisis of Islam (Antara Kepentingan Rakyat dan Kepentingan Tuhan : Demokrasi Liberal, Fundamentalisme Syariat dan Krisis Epistemologi Islam). Dari tulisan ini, kita akan menemukan kritik ideologis terhadap pemikiran politik Islam dengan pendekatan filsafat politik kontemporer yang didasari dengan teori-teori John Rawls dan Alaisdair MacIntyre. Tulisan ini dengan jelas mengemukakan tentang krisis epistemologi yang sedang dialami umat Islam terutama dalam wilayah pemikiran politik Islam ketika berhadapan dengan fenomena-fenomena modern yang dianggap sesuatu yang "asing", seperti demokrasi. Menurut Alaisdair MacIntyre, krisis epistemologi adalah sebuah kondisi dimana tradisi penyelidikan (inquiry) gagal memberikan kemajuan dengan dasar dan standar rasional. ${ }^{45}$

${ }^{41}$ Lihat Carl W. Ernst dan Richard C. Martin, "Introduction : Toward a Post-Orientalist Approach", 8.

${ }^{42}$ Lihat Carl W. Ernst dan Richard C. Martin, "Introduction : Toward a Post-Orientalist Approach", 8.

${ }^{43}$ Lihat Carl W. Ernst dan Richard C. Martin, "Introduction : Toward a Post-Orientalist Approach", 6.

${ }^{44}$ Lihat Carl W. Ernst dan Richard C. Martin, "Introduction : Toward a Post-Orientalist Approach", 2. Untuk melihat beberapa karya kontribusi para orientalisme ini bisa dibaca bagian Appendix pada tulisan Jaques Waardenburg, " Studi Islam Di Jerman", dalam Peta Studi Islam Orientalisme dan Arah Baru Kajian Islam di Barat, ed. Azim Nanji, terj. Muamiratun (Yogyakarta: Fajar Pustaka Baru, 2003), 33-41.

45"The term epistemological crisis to describe what happens when a tradition of inquiry fails to make progress by its original standards of rationality". Lihat Vincent J. Cornell, "Reason Public and Divine: Liberal Democracy, Shari'a Fundamentalism, and the 
Dengan kata lain, kecenderungan ilmiah dan rasional akan melemah sementara klaim kebenaran akan semakin kuat, dalam kasus tulisan ini dicontohkan seperti klaim kebenaran Osama bin Laden dan Said Qutb tentang ketinggian hukum Tuhan di atas hukum buatan manusia.

Untuk menghadapi krisis epistemologi tersebut, penulisnya menawarkan solusi berupa dikembangkannya sumber, kerangka pikir atau pendekatan yang baru terhadap tradisi yang merasa "tertekan" tersebut. Tentu hal ini harus diiringi dengan strategi yang khusus sehingga pengikutnya tidak merasa dihadirkan sesuatu yang asing. Strategi ini disebut oleh Alaisdair MacIntyre sebagai " new and second first language of tradition must be seen as authentic". ${ }^{46}$ Secara konkret langkahnya adalah sebagai berikut; 1) harus dimunculkan kontinuitas dari pandangan dunia tradisi yang ingin dibentuk. Dengan kata lain, yang dimunculkan adalah pandangan dunia dari tradisi itu sendiri namun dengan memberikan "pemaknaan-pemaknaan" baru sehingga objek tradisi yang hendak dibentuk tidak merasa dipaksakan oleh sesuatu yang baru atau asing. 2) sumbersumber tradisi tersebut harus berasal dari tradisi mereka sendiri, tidak boleh berasal dari luar. ${ }^{47}$

Salah satu contoh yang menggunakan strategi tersebut dan berupaya menyelesaikan problem epistemologi pemikiran politik Islam di atas adalah Feisal Abdul Rauf, seorang imam mesjid di New York dan pendiri Cordova Initiative, yang berupaya "mengawinkan" nilai-nilai universal Islam dengan HAM yang terkandung dalam Konstitusi Amerika Serikat. Tindakan yang dilakukan oleh Abdul Rauf inilah yang disebut oleh John Rawls sebagai "overlapping consensus of political rights and values". 48

Semenetara pada artikel kedua yang berjudul "Fundamentalism and The Transparency of the Arabic Quran" yang ditulis oleh A. Kevin Reinhart diungkapkan tentang hubungan ideologis antara kecenderungan fundamentalisme dan teks pramodern serta warisan struktur intelektual muslim. Pada bagian ini, penulis mengungkapkan relasi kuasa dan pengetahuan yang diusung dari bertebarannya buku-buku yang berbahasa Arab dengan kecenderungan abad pertengahan serta hubungannya dengan fundamentalisme. Tulisan ini menggambarkan bahwa untuk menegaskan kuasanya tersebut, bangsa Arab melalui para intelektualnya menekankan bahwa untuk menjadi muslim sejati harus menguasai dan mencontoh bangsa dan bahasa Arab. ${ }^{49}$ Penguasaan ini harus direfleksikan lewat pembacaan teks-teks Arab tanpa tindakan kritis terutama terhadap alquran sebab alquran dianggap sebagai kitab yang sudah jelas (the transparent text) sehingga pembacaan mereka menjadi rigid dan minim makna. Dengan cara inilah pada akhirnya lahir kecenderungan fundamentalisme tersebut. $^{50}$

Ini baru dua contoh dari kontribusi yang diberikan oleh penggunaan pendekatan-pendekatan baru yang ditawarkan studi-studi Islam era kontemporer, yang mau tidak mau harus disikapi secara dewasa dan bijak. Kritik-kritik seperti di atas tentunya akan mengejutkan sekaligus menyadarkan keberagamaan alam bawah sadar kita yang mungkin telah kaku dan ideologis. Mungkin sebelum ini, ada yang sangat mengidolakan

Epistemological Crisis of Islam", dalam Rethinking Islamic Studies, ed. Carl W. Ernst dan Richard C. Martin (Columbia : University of South Carolina Press, 2010), 29.

${ }^{46}$ Lihat Vincent J. Cornell, "Reason Public and Divine, 30.

${ }^{47}$ Lihat Vincent J. Cornell, "Reason Public and Divine, 30.

${ }^{48}$ Lihat Vincent J. Cornell, "Reason Public and Divine, 39, 41.

${ }^{49}$ Reinhart, "Fundamentalism And The Transparency of The Arabic Qur'an”, dalam Rethinking Islamic Studies, 101-102

${ }^{50}$ Reinhart, "Fundamentalism And The Transparency of The Arabic Qur'an", dalam Rethinking Islamic Studies, 97-113. 
bahasa Arab atau orang Arab sehingga terobsesi dan beranggapan bahwa Islam Arab adalah Islam autentik, namun dengan kritik ideologis di atas paling tidak bisa diambil pembelajaran agar tidak terjebak pada Islam Arab saja sebagai sesuatu yang ideal, tetapi menuju Islam sebagai agama untuk kebaikan semua manusia atau Islam yang kosmopolit.

\section{Penutup}

Pesatnya perkembangan studi Islam di Barat di atas tentunya menjadi bahan refleksi yang berharga bagi perkembangan keilmuan Islam di tempat kita masing-masing, apalagi kita sebagai muslim-lah yang lebih intensif "bergaul" dan beraktivitas dengan keislaman itu sendiri.

Upaya untuk menjadikan Islam sebagai rahmat bagi seluruh alam semesta tentunya meniscayakan penelitian-penelitian intensif dengan perangkat yang tepat sehingga mampu mengaktualisasi nilai-nilai kosmopolit Islam tersebut. Dan mungkin saja perangkat ilmu-ilmu sosial dan humaniora yang ditawarkan dalam perkembangan Barat di atas bisa membantu untuk mencapai tujuan di atas []

\section{DAFTAR PUSTAKA}

Azizy, A. Qodri. Pengembangan Ilmu-Ilmu Keislaman. Jakarta: Departemen Agama, 2003.

Azra, Azyumardi. Jaringan Ulama Timur Tengah dan Kepulauan Nusantara Abad XVII \& XVIII. Bandung: Mizan, 2004.

Baidhawy, Zakiyuddin. "Perkembangan Kajian Islam dalam Studi Agama: Sebuah Pengantar", dalam Pendekatan Kajian Islam Dalam Studi Agama, ed. Richard C. Martin. Surakarta: Muhammadiyah University Press, 2001.

Cornell, Vincent J. "Reason Public and Divine: Liberal Democracy, Shari'a Fundamentalism, and the Epistemological Crisis of Islam", dalam Retbinking Islamic Studies, ed. Carl W. Ernst dan Richard C. Martin. Columbia: University of South Carolina Press, 2010.

Ernst dan Richard C. Martin, Carl W. "Introduction: Toward a Post-Orientalist Approach to Islamic Religious Studies", dalam Rethinking Islamic Studies, ed. Carl W. Ernst dan Richard C. Martin. Columbia: University of South Carolina Press, 2010.

Jamilah, Maryam. Islam dan Orientalisme. terj. Machnum Husein. Jakarta: Rajawali Press, 1994. 
Martin, Richard C. "Islam And Religious Studies : An Introductory Essay", dalam Approaches to Islam In Religious Studies, ed. Richard C. Martin. Tucson: The University of Arizona Press, 1985.

Nasution, Harun. Islam Rasional; Gagasan dan Pemikiran. Bandung: Mizan, 1995.

Rais, M. Amien. Cakrawala Islam. Bandung: Mizan, 1986.

Reinhart, A. Kevin. "Fundamentalism And The Transparency of The Arabic Qur'an”, dalam Rethinking Islamic Studies, ed. Carl W. Ernst dan Richard C. Martin. Columbia: University of South Carolina Press, 2010.

Said, Edward W. Orientalisme. terj. Asep Hikmah. Bandung: Pustaka, 1996.

Waardenburg, Jaques. "Studi Islam Di Jerman", dalam Peta Studi Islam Orientalisme dan Arah Baru Kajian Islam di Barat, ed. Azim Nanji, terj. Muamiratun. Yogyakarta: Fajar Pustaka Baru, 2003. 
